\title{
An integrated engineering solution used for enhancing the design of a technological device for automated assembly
}

\author{
Ionut Madalin Pista*, Vasile Merticaru and Marius Ionut Ripanu \\ "Gheorghe Asachi" Technical University of Iasi, Department of Machine Manufacturing Technology, \\ Prof. D. Mangeron Street, no. 39A, Iasi, Romania
}

\begin{abstract}
The paper presents a theoretical approach and a case study upon the use of an advanced CAD solution integrated with another engineering design software solution embedding DFMA concepts, particularly applied within the product and manufacturing process design for technological devices. The main objective of implementing CAD and DfX/DFMA integrated solutions is to guide designers into the product development phase so that a better design can be achieved in a shorter time and with lower costs. The case study analyzes an assembly model developed for an indexing mounting table dedicated for the automated assembling of an industrial electrical plug inlet. The assembly product model has been developed using 3D parametric modeling specific tools, further on it has been subjected to analysis based on DFMA principles and after that its components have been redesigned to respond to the analysis results. Some of the case study results and their interpretation are discussed in the paper content and finally some overall conclusions are included along with some intended future research directions.
\end{abstract}

\section{Introduction. Problem statement}

In order to survive within a competitive global market, manufacturers need to find solutions to reduce overall manufacturing costs, to achieve products in a shorter time and with higher quality and to deliver products in time [1]. In order to face this growing complexity, the field of theories and design methodologies is full of tools and principles developed to structure the design process [2]. A methodology we find useful to meet such requirements is Concurrent Engineering (CE). Accordingly to Huang [3], CE improves quality, reduces costs, compresses cycle time, increases flexibility, increases productivity and efficiency, and improves the social image, making an ideal environment for product development. CE can be viewed as a simultaneous development of the entire project by applying design methodologies during the product development process, such as Design for eXellence (DfX), DFMA (Design for Manufacturing and Assembly), Computer Aided Design (CAD), Computer Aided Engineering (CAE), Computer Aided Manufacturing (CAM) etc. [4].

\footnotetext{
*Corresponding author: ionutpista@yahoo.com
} 
The approach further on presented in the paper is part of a broader research where conceptual models for optimizing the design process by incorporating of some design tools and philosophies such as AD and DfX [5], respectively DFD-DFR [6], were proposed. A case study on optimizing the manufacturing process by integrating some CAD/CAE design tools, including embedding some DfX/DFM principles, has been further on developed.

\section{Theoretical backgrounds. Research problem substantiation}

Numerous sources point out that over $70 \%$ of the final cost of the product is determined in the design phase, while the actual cost of the design phase represents about $5 \%$ of the cost of the product [7]. These values show that the design phase plays a major role in the life cycle of the product, extensive researches being realized and leading to the development of many design tools and methodologies, reunited under the name of DFx. DFx philosophies represent some of the most effective approaches for implementing the Concurrent Engineering The variable term " $\mathrm{x}$ " can be replaced, for example with: Assembly, Cost, Environment, Manufacturing, Processing, Acquisition, Reliability, Maintenance or Test, among other process characteristics from the product life cycle [3].

The most common meanings for DFx are Design for Manufacturing (DFM) and Design for Assembly (DFA), these being the first used DFx methods. Taking into account manufacturing and assembly issues in the product design phase is, therefore, the most costeffective way to reduce assembly costs and to increase productivity. The principles of DFA have the role to simplify the product by reducing the number of components by eliminating or integrating them with other parts, thereby improving the quality of the product and minimizing assembly problems. The DFM philosophy determines the design of a product with minimal manufacturing costs and high-quality production by choosing the most appropriate manufacturing techniques and practices [8].

Integration of some software solutions for manufacturing processes analysis with $\mathrm{CAD} / \mathrm{CAE} / \mathrm{CAM}$ specific design environments assists engineers in the design process to provide optimal solutions for the achieved product and process models [9].

Currently, DFMA software tool [10] is widely applied along with CAD/CAE systems in which the designer can analyze the characteristics of a modeled product to anticipate costs and determine manufacturing and assembling processes. This allows the project to be modified and to choose the best product engineering solutions.

The paper presents bellow an example of design improvement based on DFM considerations upon the manufacturing, through specific machining processes, of the components from an automated assembly device. An analysis like the one subjected to discussion usually focuses on a particular manufacturing domain or process, through which the parts are to be made, respectively turning, milling, casting, injection molding, stamping, etc. [11]. In order to support the above presented statements, the included case study follows the application of DFM design principles on products manufacturing analysis using specific software tools like SolidWorks [12] and DFM Pro [13].

\section{Case study. Results and interpretations}

The case study hereby exemplified is part of a larger research, partially presented in previous works where the issues of DFMA [5] and AD [14] were treated. The object of the case study is a device for the automated assembly (Figure 1) of an electrical plug inlet. The device performs a circular transport movement and consists of five workstations that correspond to each stage of the assembly process. The initial version of the product has been previously designed [15] based on applying some creativity methods [16]. 


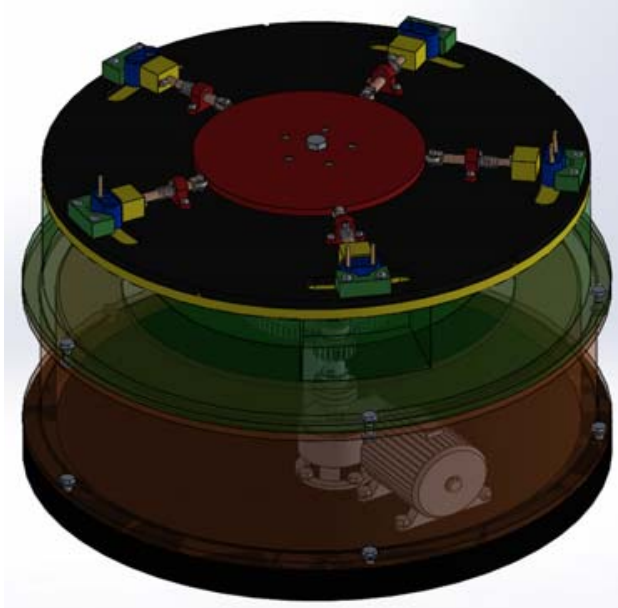

Fig. 1. 3D parameterized assembly model for the indexing mounting table [5].

Using a selection of the advanced design capabilities offered by Solid Works [17] and DFM Pro (trial version) CAD/CAE tools, the 3D model of the automatic assembly device was developed and analyzed by the application of DfX/DFM techniques.

The indexing mounting table is compound of a set of miscellaneous parts, and their 3D design models are presented in Table 1. For each part, in the assembly sequence, the manufacturing function difficulties were analyzed and evaluated with the above nominated specific software.

DFM principles have been applied in detail from the design stage, one of the most important tasks for the manufacturing analysis being the selection of the manufacturing processes for the parts and the material assigned to them. Thus, the DFM Pro analysis tool provided a set of design rules and suggestions on manufacturing, for a number of six machining processes, which had to be chosen depending on how the analyzed component is made. After that, an analysis report has been provided to view and to interpret the design of the part, and if necessary to redesign or to correct the design.

Table 1. CAD models of indexing mounting table parts.

\begin{tabular}{|c|c|c|c|c|c|}
\hline $\begin{array}{c}\text { Part } \\
\text { Name } \\
\end{array}$ & 3D Model & $\begin{array}{l}\text { Part } \\
\text { Name }\end{array}$ & 3D Model & $\begin{array}{l}\text { Part } \\
\text { Name }\end{array}$ & 3D Model \\
\hline $\begin{array}{l}\text { Base } \\
\text { plate }\end{array}$ & & $\begin{array}{l}\text { Cam } \\
\text { shaft }\end{array}$ & & $\begin{array}{l}\text { Follower } \\
\text { rod }\end{array}$ & \\
\hline $\begin{array}{l}\text { Bottom } \\
\text { housing }\end{array}$ & & $\begin{array}{l}\text { Tubular } \\
\text { shaft }\end{array}$ & & Roller & \\
\hline $\begin{array}{l}\text { Upper } \\
\text { housing }\end{array}$ & & $\begin{array}{l}\text { Bearing } \\
\text { bushing }\end{array}$ & & $\begin{array}{l}\text { Guiding } \\
\text { element }\end{array}$ & \\
\hline $\begin{array}{l}\text { Support } \\
\text { crown }\end{array}$ & & $\begin{array}{l}\text { Flexible } \\
\text { coupling }\end{array}$ & & $\begin{array}{l}\text { Fixing } \\
\text { jaw }\end{array}$ & \\
\hline $\begin{array}{l}\text { Rotary } \\
\text { table }\end{array}$ & & $\begin{array}{l}\text { Spur } \\
\text { gear }\end{array}$ & & Prism & \\
\hline Cam & & $\begin{array}{l}\text { Worm } \\
\text { gear }\end{array}$ & & $\begin{array}{l}\text { Worm } \\
\text { gearbox }\end{array}$ & \\
\hline
\end{tabular}


One representative part of the studied device is the cam shaft and it has been analyzed for the main machining process through which it is manufactured, respectively turning. The initial analysis report (Table 2) revealed that the analyzed part does not meet a number of five rules regarding the selected manufacturing process, such as: internal sharp corner, flat bottom of the hole, outer diameter profile relief, non-standard hole (Figure 2-a). Interpretation of the results has allowed the identification of some improvement solutions (standardizing selected hole, applying internal corner radius, chamfer and conical bottom for the hole) which led to the redesign of this component (Figure 2-b) and these rules were fulfilled except one, because the signalized surface has a functional role, representing a support shoulder for mounting a radial ball bearing, and that rule was accepted (Table 3 ).

Table 2. Initial DFM Pro analysis report for Cam shaft.

\begin{tabular}{|c|c|c|c|c|c|}
\hline \multirow{2}{*}{ DFMPro Analysis Report } & \multicolumn{2}{|c|}{ Rules not applicable [33/53] } & \multirow{3}{*}{\begin{tabular}{|c|} 
Rules passed [15/53] \\
Part Name - Cam Shaft \\
Message
\end{tabular}} & \multirow{2}{*}{\multicolumn{2}{|c|}{$\frac{\text { Rules failed [5/53] }}{\text { DFM Report - \#01 }}$}} \\
\hline & Design For & - Turn & & & \\
\hline Rule Name & $\begin{array}{c}\text { Number of failure } \\
\text { Instances }\end{array}$ & Instance & & Actual Value & Status \\
\hline \multirow{3}{*}{$\begin{array}{l}\text { Minimum Internal Corner } \\
\text { Radius }\end{array}$} & \multirow{3}{*}{$3 / 3$} & Instance $[1]$ & $\begin{array}{l}\text { Minimum Corner Radius: } \\
\text { Actual Value }=0.0 \mathrm{~mm} \\
\text { Recommended Value }>=0.5 \mathrm{~mm}\end{array}$ & $0.0 \mathrm{~mm}$ & \\
\hline & & Instance[2] & $\begin{array}{l}\text { Minimum Corner Radius: } \\
\text { Actual Value }=0.0 \mathrm{~mm} \\
\text { Recommended Value }>=0.5 \mathrm{~mm}\end{array}$ & $0.0 \mathrm{~mm}$ & \\
\hline & & Instance[3] & $\begin{array}{l}\text { Minimum Corner Radius: } \\
\text { Actual Value }=0.0 \mathrm{~mm} \\
\text { Recommended Value }>=0.5 \mathrm{~mm}\end{array}$ & $0.0 \mathrm{~mm}$ & \\
\hline \multirow{2}{*}{ OD Profile Relief } & \multirow{2}{*}{$2 / 7$} & Instance[1] & $\begin{array}{l}\text { Actual value }=90.0 \mathrm{deg} \\
\text { Recommended value } \quad<=58.0 \mathrm{deg} .\end{array}$ & $90.0 \mathrm{deg}$ & \\
\hline & & Instance[2] & $\begin{array}{l}\text { Actual value }=90.0 \mathrm{deg} \\
\text { Recommended value } \quad<=58.0 \mathrm{deg} .\end{array}$ & $90.0 \mathrm{deg}$ & \\
\hline $\begin{array}{l}\text { Long - Slender Turned } \\
\text { Parts }\end{array}$ & $1 / 1$ & Instance[1] & $\begin{array}{l}\text { Minimum Diameter }(\mathrm{D})=0.01 \mathrm{~mm} \\
\text { Axial Length }(\mathrm{L})=0.36 \mathrm{~mm} \\
\text { Aspect Ratio }(\mathrm{L} / \mathrm{D}): \\
\text { Actual Value }=26.07 \\
\text { Recommended Value }<=8.0 \text { (Either Diameter } \\
\text { should be }>0.05 \mathrm{~mm} \text { or Axial length }<=0.08 \\
\mathrm{~mm} \text { ) }\end{array}$ & 26.07 & \\
\hline Flat Bottom Holes & $1 / 1$ & Instance[1] & $\begin{array}{l}\text { Hole Diameter }=10.92 \mathrm{~mm} \\
\text { Maximum Drill Diameter }=45.0 \mathrm{~mm} \\
\text { Hole Diameter }<=\text { Maximum Drill Diameter } \\
\text { Hole Type: } \\
\text { Actual Value = Flat Bottom Hole } \\
\text { Recommended Value = Conical Bottom Hole }\end{array}$ & $\begin{array}{l}\text { Flat Bottom } \\
\text { Hole }\end{array}$ & \\
\hline Standard Hole Sizes & $1 / 1$ & Instance[1] & $\begin{array}{l}\text { Hole Diameter: } \\
\text { Actual Value }=10.92 \mathrm{~mm} \\
\text { Recommended Value }=10.8 \mathrm{~mm} \text { or } 11.0 \mathrm{~mm}\end{array}$ & $10.92 \mathrm{~mm}$ & \\
\hline
\end{tabular}

Table 3. DFM Pro analysis report for redesigned Cam shaft.

\begin{tabular}{|c|c|c|c|c|c|}
\hline \multirow[t]{2}{*}{ DFMPro Analysis Report } & \multirow{2}{*}{\multicolumn{2}{|c|}{$\frac{\text { Rules not applicable [33/53] }}{\text { Design For - Turn }}$}} & \multirow{3}{*}{\begin{tabular}{|c} 
Rules passed [19/53] \\
Part Name - Cam Shaft \\
Message
\end{tabular}} & \multirow{2}{*}{\multicolumn{2}{|c|}{$\begin{array}{l}\text { Rules failed [1/53] } \\
\text { DFM Report - \#02 }\end{array}$}} \\
\hline & & & & & \\
\hline Rule Name & $\begin{array}{c}\text { Number of } \\
\text { failure Instances }\end{array}$ & Instance & & Actual Value & Status \\
\hline \multirow{3}{*}{$\begin{array}{c}\text { Minimum Internal Corner } \\
\text { Radius }\end{array}$} & \multirow{3}{*}{ 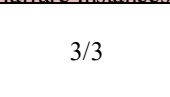 } & Instance [1] & Minimum Corner Radius: & $0.0 \mathrm{~mm}$ & Passed \\
\hline & & Instance[2] & Minimum Corner Radius: & $0.0 \mathrm{~mm}$ & Passed \\
\hline & & Instance[3] & Minimum Corner Radius: & $0.0 \mathrm{~mm}$ & Passed \\
\hline \multirow[t]{2}{*}{ OD Profile Relief } & \multirow[t]{2}{*}{$2 / 7$} & Instance[1] & $\begin{array}{l}\text { Actual value }=90.0 \mathrm{deg} \\
\text { Recommended value } \quad<=58.0 \mathrm{deg} .\end{array}$ & $90.0 \mathrm{deg}$ & Accepted \\
\hline & & Instance[2] & Recommended value $\quad<=58.0 \mathrm{deg}$. & $45.0 \mathrm{deg}$ & Passed \\
\hline $\begin{array}{c}\text { Long - Slender Turned } \\
\text { Parts } \\
\end{array}$ & $1 / 1$ & Instance[1] & $\begin{array}{l}\text { Minimum Diameter (D) } \\
\text { Axial Length (L) }\end{array}$ & 7.86 & Passed \\
\hline Flat Bottom Holes & $1 / 1$ & Instance [1] & $\begin{array}{l}\text { Recommended Value }=\text { Conical } \\
\text { Bottom Hole }\end{array}$ & $\begin{array}{c}\text { Conical Bottom } \\
\text { Hole }\end{array}$ & Passed \\
\hline Standard Hole Sizes & $1 / 1$ & Instance[1] & Hole Diameter: & $10 \mathrm{~mm}$ & Passed \\
\hline
\end{tabular}



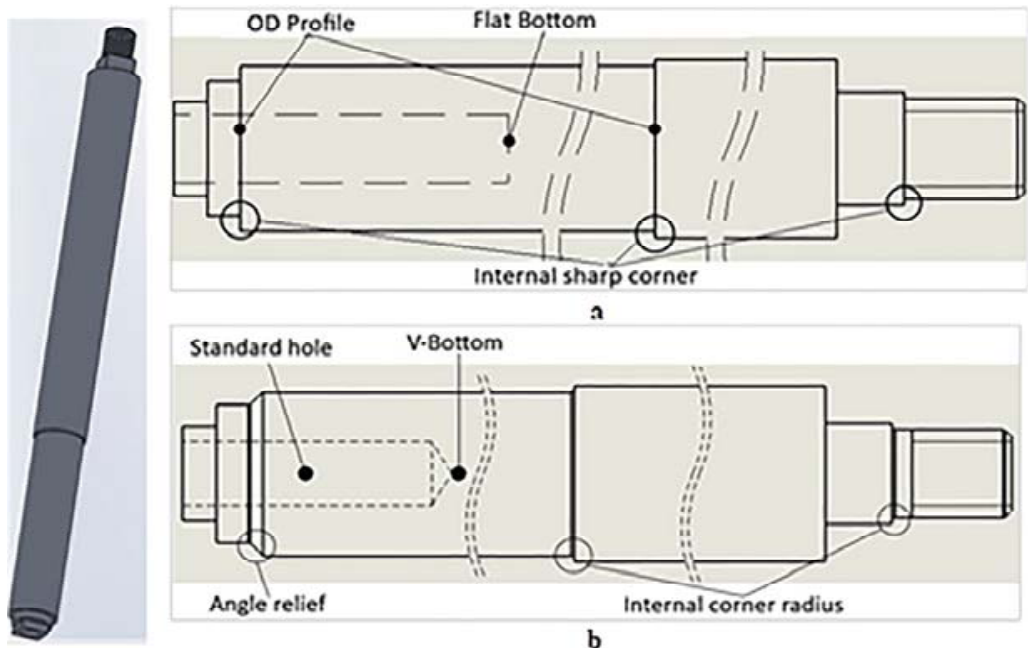

a

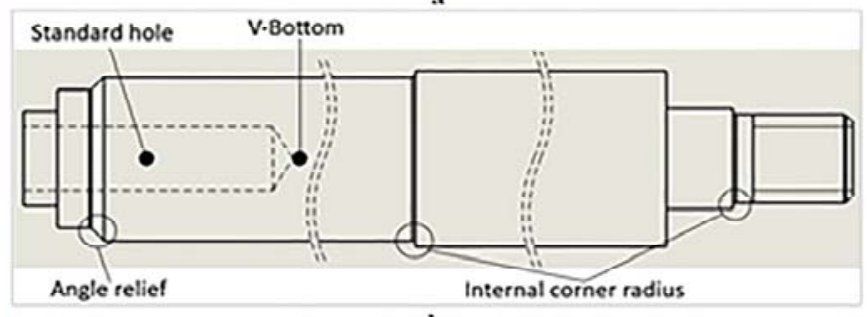

b

Fig. 2. SolidWorks 3D parameterized model for Cam shaft. a) Initial part design. b) Part design after DFM Pro analyze.

Another analyzed part of the automated assembly device, selected to be exemplified here, is the prism, which is machined by milling (Figure 3 ). The analysis report provided by the used software (Table 4) has suggested to make some connection radius or chamfer to remove sharp edges that are hard to machining. Taking into account this improvement solution has led to optimizing the design of this component (Figure 3-b) in order to be manufactured in favorable technical-economic conditions.
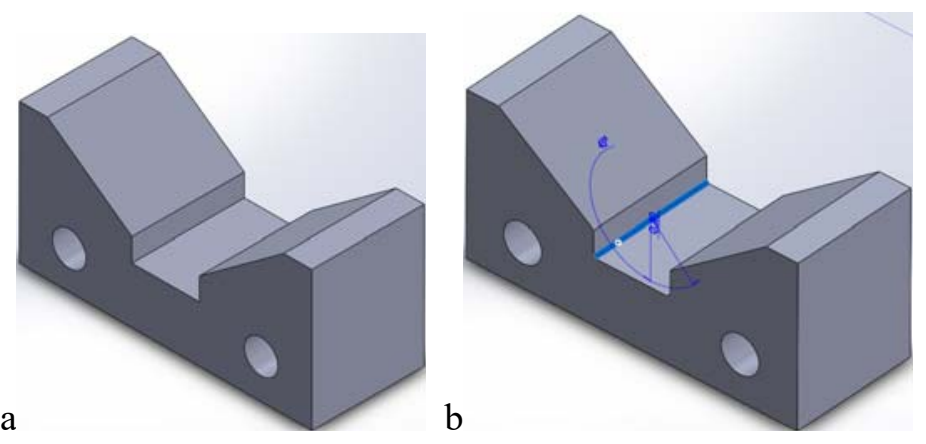

Fig. 3. Solid Works 3D parameterized model for the prism. a) Initial design. b) Design after DFM Pro analyze.

Table 4. DFM Pro analysis report for Prism.

\begin{tabular}{|c|c|c|l|c|}
\hline DFMPro Analysis Report & Rules not applicable [39/53] & Rules passed [13/53] & Rules failed [1/53] \\
\hline & Design For - Prismatic Mill & Part Name - Prism & DFM Report - \#01 \\
\hline Rule Name & $\begin{array}{c}\text { Number of } \\
\text { failure Instances }\end{array}$ & Instance & Message & Actual Value \\
\hline Sharp Internal Corners & $1 / 1$ & Instance[1] & $\begin{array}{c}\text { Actual Value = Sharp Corner Present } \\
\text { Recommended Value = Avoid Sharp Corner }\end{array}$ & Sharp Corner Present \\
\hline
\end{tabular}

Similar analyses have been accomplished for all component parts of the automated assembly device and the interpretation of the obtained analysis reports have allowed corrections or validation of the final parts designs. 


\section{Conclusions}

The results presented above in this paper and others similar obtained in the described case study, have confirmed the advantages of using integrated designing and analysis systems such as SolidWorks and DFM Pro in designing a new product as well as redesigning an existing product.

Particular solutions of improvements for the geometry of the components of the analyzed automated assembly device, provided by the DFM Pro tool, have enabled an easy re-engineering of the product for a better manufacturability.

The applying of DfX/DFMA principles from the incipient design phases, easy to achieve using dedicated software tools, able to be integrated within advanced CAD/CAE applications, enables early identification of some specific ways to improve technical specifications for designed products, increasing the efficiency and effectiveness of specific designing activities.

For the future, there may be declared the intention to extend these researches on other aspects related to the principles and philosophies of DfX and Design Thinking within the wider frame of Product Development Process (PDP).

\section{References}

1. C.K. Choi, D.S.K. Chan, A.M.F. Yuen, Int J Adv Manuf Technol, 19, 377-383 (2002)

2. V. Merticaru, M.I. Ripanu, Applied Mechanics and Materials 371, 499-503 (2013)

3. G.H. Huang, Design for X: Concurrent Engineering Imperatives (Chapman \& Hall, London, UK, 1996)

4. J.G. Azevedo, A.C. Arantes Filho, L.E.V.L. Costa, J. Aerosp. Technol. Manag., São José dos Campos, Vol.7, No 1, 93-100, Jan.-Mar. (2015)

5. I.M. Pista, V. Merticaru, G. Nagît, M.I. Rîpanu, MATEC Web of Conferences 137, 04006 (2017)

6. M.M. Cucos et al., Bulletin of the Polytechnic Institute of Iasi, Machine Construction 63(67) no.3, 21-40 (2017)

7. S. Munro, D. Foreman, D. McCarthy, I. Chambers, Thomas, Lean Design: Value Quality Profit (Munro Assoc Inc, 2013)

8. G. Boothroyd, P. Dewhurst, W.A. Knight, Product Design for Manufacture and Assembly (Marcel Dekker, New York, 1994)

9. V. Merticaru, G. Nagit, B. Pralea, R. Oana, AJME 12, 43-48 (2014)

10. Boothroyd Dewhurst Inc., DFMA software tool (2017)

11. J.G. Bralla, Design for Manufacturability Handbook, Second Edition (McGraw-Hill, New York, 1999)

12. Dassault Systèmes SOLIDWORKS Corp., SolidWorks (2017)

13. GEOMETRIC, DFMPro for SolidWorks (2017)

14. I.M. Pista et al., Bulletin of the Polytechnic Institute of Iasi, Machine Construction 63(67) no.3, 9-20 (2017)

15. I.M. Pista, Bachelor Thesis (TUIASI, 2013)

16. G. Nagit, Techniques and methods of creativity stimulation (in Romanian) (TehnicaInfo, Kishinev, 2001)

17. V. Merticaru et al, Annals of the Oradea University, Fascicle of Management and Technological Engineering XI (XXI), no.2, 4.63-4.72 (2012) 